\title{
FENOMENA KUALITAS HIDUP ORANG DENGAN HUMAN IMUNNODEFICIENCY VIRUS/ ACQUIRED IMUNNO DEFICIENCY SYNDROME DI KABUPATEN BANDUNG BARAT
}

\author{
PEOPLE'S QUALITY PHENOMENA WITH HUMAN IMMUNODEFICIENCY VIRUS / \\ ACQUIRED IMMUNE DEFICIENCY SYNDROME IN WEST BANDUNG DISTRICT
}

\author{
Leminaria Naibaho', Palupi Triwahyuni ${ }^{2}$, Jeanny Rantung ${ }^{3}$ \\ Fakultas IImu Keperawatan Universitas Advent Indonesia \\ Email: -
}

\begin{abstract}
ABSTRAK
Pendahuluan: Human Immunodeficiency Virus (HIV) /Acquired Immuno Deficiency Syndrome (AIDS) adalah sekumpulan gejala dan infeksi atau sindrom yang timbul karena rusak sistem kekebalan tubuh manusia akibat infeksi virus HIV. Virus HIV menyebabkan kekebalan tubuh manusia menjadi lemah. Tujuan dari penelitian ini adalah untuk mengetahui gambaran kualitas hidup orang dengan HIV AIDS di Kabupaten Bandung Barat. Metode yang digunakan pada penelitian ini adalah metode kualitatif dengan tehnik snowball sampling (sampel bola salju). Populasi yang digunakan dalam penelitian ini adalah Orang Dengan HIV/AIDS di Kabupaten Bandung Barat berjumlah 6 orang. Hasil penelitian menunjukkan bahwa kualitas hidup orang dengan HIV dan AIDS di Kabupaten Bandung Barat adalah Ke-6 informan mengalami perubahan secara fisik, psikologis, sosial, dan lingkungan setelah terdiagnosa positif HIV dan AIDS. Dari segi spiritual tidak mengalami perubahan. Hasil penelitian ini diharapkan sebagai masukan untuk memberikan pengetahuan tentang HIV/AIDS dan cara pencegahannya agar ODHA memiliki kualitas hidup yang baik. Bidang keperawatan diharapkan dapat menambah khasanah bagi ilmu keperawatan khususnya dalam memberikan asuhan keperawatan pada pasien HIV/AIDS. Dalam bidang penelitian agar penelitian ini dapat dikembangkan sebagai dasar untuk bahan penelitian selanjutnya mengenai stigma masyarakat terhadap ODHA di Kabupaten Bandung Barat.
\end{abstract}

Kata Kunci: Kualitas Hidup, Human Immunodeficiency Virus (HIV) / Acquired Immuno Deficiency Syndrome (AIDS).

\begin{abstract}
Introduction: The Human Immunodeficiency (HIV)/Acquired Immuno Deficiency Syndrome (AIDS) is a collection of symptoms and an infection or a syndrome arises from a derangement of the human immune system caused by infectious virus of HIV. The virus of HIV cause immune to the human body to be weak. The purpose of this research is to know the quality of life people with HIV AIDS in the district of West Bandung. The method used in this study is the method of a qualitative with the snowball sampling (sample a snowball fight). The population used in this study a person With HIV / AIDS in the district of West Bandung wich amounted to 6 people. The results showed that the quality of life for people with HIV and AIDS in the district of West Bandung is the informant had been changed in physical, psychological, social, and the environment after diagnosed HIV positive and AIDS. In terms of spiritual not changed. The results are expected as input to provide knowledge about HIVIAIDS and means of prevention to ODHA have a very good quality of life. of nursing is expected to add to the repertoire for nursing science, especially in providing care nursing at the patient's HIV / AIDS. In the field of research for this research can be developed as a basic for further research on stigma to ODHA in the district of West Bandung.
\end{abstract}

Keywords: Quality Of Life, Human Immuno Deficiency Virus (HIV) / Acquired Immuno Deficiency Syndrome (AIDS).
JURNAL 


\section{PENDAHULUAN}

Maraknya penyakit yang mematikan saat ini membuat individu mawas diri. Banyak usaha yang dilakukan individu untuk mencegah penyakit tersebut. Salah satu penyakit yang mematikan itu adalah Human Immunodeficiency Virus (HIV) /Acquired Immuno Deficiency Syndrome (AIDS).

Menurut Syafrudin (2011. hlm. 302) AIDS adalah sekumpulan gejala dan infeksi atau sindrom yang timbul karena rusak sistem kekebalan tubuh manusia akibat infeksi virus HIV. Virus HIV menyebabkan kekebalan tubuh manusia menjadi lemah. Orang yang terkena virus HIV akan menjadi rentan terhadap setiap jenis penyakit infeksi. Saat ini penanganan terhadap virus HIV hanya memperlambat laju perkembangan virus, dengan kata lain penyakit ini belum dapat disembuhkan.

Buchanan (2010) menyebutkan kualitas hidup didefenisikan secara fungsional sebagai persepsi pasien sendiri terhadap kinerja secara fisik, pekerjaan, psikologis, dan keuangan. Menurut Preddy dan Watson (2010. hlm. 382) kualitas hidup adalah persepsi masing-masing individu dalam kehidupan termasuk konteks budaya dan sistem nilai kehidupannya berkaitan dengan tujuan, harapan, dan kekhawatiran hidup.

Penelitian yang dilakukan oleh Hardiansyah, Amiruddin, dan Arsyad pada tahun 2014 di Makassar tentang "kualitas hidup orang dengan HIV AIDS" yang dilakukan pada 21 ODHA menggunakan teknik accidental sampling. Penelitian yang dilakukan adalah penelitian deskriptif dengan menggunakan instrument WHOQOL-HIV BREF, yang terdiri dari enam domain. Hasil penelitian menunjukkan bahwa untuk domain fisik yang memiliki kualitas hidup baik sebanyak 38,1\% dan kurang baik 61,9\%. Domain psikologi yang memiliki kualitas hidup baik sebanyak $23,8 \%$ dan kurang baik $76,2 \%$.

Pada domain tingkat kemandirian kualitas hidup baik sebanyak $28,6 \%$ dan kurang baik $71,4 \%$. Domain interaksi sosial, memiliki kualitas hidup baik $38,1 \%$ dan kurang baik $61,9 \%$ dan domain spiritual yang memiliki kualitas hidup baik sebanyak 47,6\% dan kurang baik 52,4\%. Penelitian tersebut menyimpulkan dari keenam domain responden yang mendapatkan kualitas hidup baik $47,6 \%$, sedangkan yang mendapatkan kualitas hidup buruk sebanyak 52,4\% (Hardiansyah, Amiruddin, dan Arsyad, 2014, hlm. 5).

Berdasarkan data dari Komisi Penanggulangan Aids (KPA) di Kabupaten Bandung Barat, mengatakan jumlah penderita HIV / AIDS tahun 2007-2015 adalah 170 kasus diantaranya 154 kasus di wilayah Kabupaten Bandung Barat dan 13 kasus diluar wilayah bahkan angka mortalitas akibat HIV/AIDS adalah 19 orang (KPA Kabupaten Bandung Barat,2015).

\section{BAHAN DAN METODE}

Metode yang digunakan dalam penelitian ini adalah metode kualitatif dengan tehnik snowball sampling (sampel bola salju). Indrawan dan Yaniawati, (2014. hlm. 107) mengatakan bahwa metode snowball sampling adalah suatu metode yang memilih 1 atau 2 informan kunci, kemudian meminta informan sebelumnya mengusulkan informan berikutnya. Adapun tujuannya adalah untuk memfasilitasi identifikasi fenomena yang ingin diamati. Pada penelitian ini metode snowball sampling digunakan untuk mendapatkan kualitas hidup orang dengan HIV/AIDS di Kabupaten Bandung Barat.

\section{PEMBAHASAN}

Hasil penelitian berdasarkan wawancara indepth interview terhadap ke-6 informan ODHA di Kabupaten Bandung Barat selama 3 hari berturut-turut bahwa Kualitas hidup ODHA di Kabupaten Bandung Barat dari segi fisik mengalami perubahan yaitu: flu, batuk, kulit menghitam, kutil kelamin, tb paru, dan penurunan berat badan. Kualitas hidup ODHA di Kabupaten Bandung Barat dari segi psikologis mengalami perubahan yaitu: cemas, stres, kaget, drop dan kecewa. 
Kulaitas hidup ODHA di Kabupaten Bandung Barat dari segi sosial adalah merahasiakan status penyakit dari keluarga dan lingkungan. Kualitas hidup ODHA di Kabupaten Bandung Barat dari segi spiritual memiliki kualitas hidup baik karena rajn ibadah. Kualitas hidup ODHA di Kabupaten Bandung Barat dari segi lingkungan tidak mengalami perubahan karena ODHA menyembunyikan status penyakit, kualitas hidup ODHA dari segi fisik.

\section{HASIL}

Hasil yang dianalisa dalam penelitian ini berdasarkan wawancara indepth interview bahwa kualitas hidup ODHA dari segi fisik, psikologis, spiritual mengalami perubahan. Dari segi sosial dan lingkungan tidak mengalami perubahan.

\section{KESIMPULAN}

Kualitas hidup ODHA di Kabupaten Bandung Barat dari segi fisik, dan psikologis mengalami perubahan. Sedangkan dari segi sosial, spiritual dan lingkungan tidak mengalami perubahan.

\section{DAFTAR PUSTAKA}

Amiruddin, R., \& Arsyad, D. S. (2014). Kualitas Hidup Orang Dengan HIV/AIDS Di Kota Makassar.

Afiyah, R. K. (2010). Kualitas Hidup Perempuan yang Mengalami Histerektomi serta Faktor- Faktor yang Mempengaruhinya di Wilayah DKI Jakarta: Study Grounded Theory. Tesis. FIK UI.

Astuti, A., \& Budiyani, K. (2010). Hubungan Antara Dukungan Sosial Yang Diterima Dengan Kebermaknaan Hidup Pada Odha (Orang Dengan HIV/AIDS)." Jurnal Insight.

Buchanan. 2010. Quality of Life Fungtional. Jakarta: PT Raja Grafindo Persada.

Bungin, B. (2014). Peneltian Kualitatif. Jakarta: Prenada Media Group.
Caroline Bunker Rosdahl, M. T. (2015). Buku Ajar Keperawatan Dasar (10 ed., Vol. 4). Jakarta: Penerbit Buku Kedokteran EGC.

Dewi, N. S. (2010). Pengaruh Pendidikan Kesehatan Terhadap Perubahan Pengetahuan Dan Sikap Dalam Pencegahan Hiv/Aids Pada Pekerja Seks Komersial. Nurse Media Journal of Nursing, 2(1).

Diatmi, K., \& Fridari, I. G. A. (2014). Hubungan Antara Dukungan Sosial dengan Kualitas Hidup pada Orang Dengan HIV dan AIDS (ODHA) Di Yayasan Spirit Paramacitta. Jurnal Psikologi Udayana, 1(02).

Dyagustin, E., \& Listyani, R H. (2015). Konstruksi Orang Dengan Hiv\&Aids (Odha) Tentang Penyakit Hiv\&Aids Di Kelompok Dukungan Sebaya Jombang Care Center Kabupaten Jombang. Jurnal Mahasiswa Teknologi Pendidikan, 3/(3).

Direktorat Jendral PP dan PL Kementrian Kesehatan RI. Laporan Situasi Perkembangan HIV/AIDS di Indonesia s.d. 30 juni 2012. Jakarta (Indonesia): 2012.

Ferris, A. L. 2010. Approaches to Improving the Quality of life. Freddy,V. R. dan Watson, R. R. 2010. Handbook of Disease Burdens and Quality of life measure.

Galistiani, G. F., \& Mulyaningsih, L. (2013). Kepatuhan Pengobatan Antiretroviral Pada Pasien Hiv/Aids Di Rsud Prof. Dr. Margono Soekarjo Purwokerto. Media Farmasi, 10(2).

Hidayati, U. (2015). Pengaruh Efek Samping Pemberian Terapi Antiretroviral Terhadap Kepatuhan Terapi Antiretroviral Pada Pasien Hiv/Aidsdi Klinik Counseling.Proceedin, 227. 
Hidayat, O., \& Giyarsih, S. R. (2012). Tingkat Pengetahuan Mahasiswa Universitas Gadjah Mada Tentang Bahaya Penyakit AIDS. Jurnal Bumi Indonesia, 1(2).

Hoffmann, Rockstroh, Kamps. 2010. HIV Medicine 2010. www.hivmedicine.com. Paris Fiying Publisher.

Irianto, K. (2014). Epidemiologi Penyakit menular \& Tidak Menular. Bandung: Alfabeta.

Larasaty, N. D. (2015). Bentuk- Bentuk Dukungan Keluarga Kepada lbu Dengan Hiv Positif Dalam Menjalani Terapi Arv (Studi Kasus Pada Kelompok Dukungan Sebaya/KDS Arjuna Plus Kota Semarang). InPROSIDING SEMINAR NASIONAL.

Mary Digiulio, D. J. (2014). Keperawatan Medikal Bedah. Yogyakarta: Rapha publishing.

Myers, D. (2010). Psychology. Ninth edition. Newyork: Worth Publisher.

Nursalam, N. D. (2013). Asuhan Keperawatan Pada Pasien Terinfeksi HIV/AIDS. Jakarta: Salemba Medika.

Osborn, W. W. (2014). Medical Surgical Nursing preparation for Practice. Julie Levin Alexander.

Patilima, H. 2014. Metode Penelitian Kualitatif . Bandung: Alfabeta

Paputungan, K. (2013). Dinamika Psikologis Pada Orang Dengan HIV dan AIDS (ODHA). EMPATHY Jurnal Fakultas Psikologi, 2(1).

Payuk, I., A.A., dan Abdullah. Z. (2012). Hubungan Dukungan Sosial Dengan Kualitas Hidup Orang Dengan Hiv/ Aids Di Puskesmas Jumpandang Baru Makassar Tahun 2012. Makassar: Universitas Hasanudin.
Rachmawati, S. (2013). Kualitas hidup orang dengan HIV/AIDS yang mengikuti terapi antiretroviral. Jurnal Sains dan Praktik Psikologi, 1(1).

Rusmawati, A. (2015). Persepsi Konsep Diri Orang Dengan Hiv/Aids (Odha) Dalam Kelompok Dukungan Sebaya (Kds) Di Kota Dan

Kabupaten Kediri. Jurnal Strada, 1(1). Sarafino E. (2011) Health Psychology: Biopsychosocial interactions (7 th ed). Canada: John Wiley \& Sons, Inc.

Sarikusuma, H., Hasanah, N., \& Herani, I. (2012). Konsep diri orang dengan HIV dan AIDS (ODHA) yang menerima label negatif dan diskriminasi dari lingkungan sosial. Psikologia: Jurnal Pemikiran dan Penelitian Psikologi, 7(1).

Shaluhiyah, Z., Musthofa, S. B., \& Widjanarko, B. (2015). Stigma Masyarakat terhadap Orang dengan HIV/AIDS. Kesmas: Jurnal Kesehatan Masyarakat Nasional, 9(4), 333-339.

Siboro, H. K. (2014). Pengaruh Dukungan Keluarga Terhadap Keberfungsian Sosial Orang Dengan HIV/AIDS (ODHA) di Rumah Singgah Caritas PSE Medan. Welfare StatE, 2(4).

Simboh, F.K., Bidjuni, H., \& Lolong, J. (2015). Hubungan Dukungan Keluarga Bagi Kualitas Hidup Orang Dengan Hiv/Aids (Odha) Diklinik Vct Rsu Bethesda Gmim Tomohon. Jurnal Keperawatan, 3 (2).

Sugiyono. (2014). metode penelitian kuantitatif kualitatif dan R\&D. Bandung: ALFABETA, CV.

Sunaryati, S.S. 2011. 14 Penyakit Paling Sering Menyerang Dan Sangat Mematikan. Yogyakarta: FlashBooks.

Superkertia, I., Astuti, I. W., \& Lestari, M. P. L. (2016). Hubungan Antara Tingkat Spiritualitas Dengan Tingkat Kualitas 


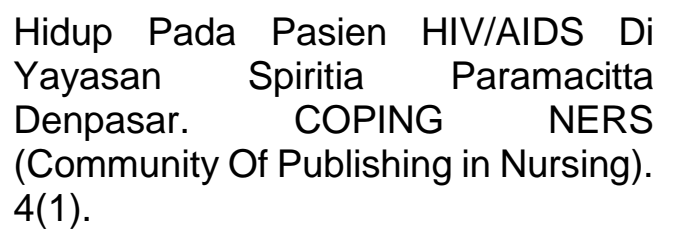

Suryoprajogo, N. (2010). Kupas Tuntas Kesehatan Remaja. Jogjakarta: Dilglossia Printika. Sylvia A. Price, L. M. (2013). Patofisiologi Konsep Klinis Proses-proses Penyakit (Vol. 1). ( $\mathrm{H}$. Hartanto, Trans.) Jakarta: Penerbit Buku Kedokteran EGC.

Team, R. (2012). Kualitas Hidup Wanita Penderita AIDS Dan Wanita Pasangan Penderita AIDS di Kabupaten Bandung Barat. Majalah Keperawatan Unpad, 10.18 (2012).

Yayasan Spiritia. 2013. Lembaran Informasi tentang HIV/AIDS untuk ODHA. Jakarta: Yayasan Spiritia, The Ford Foundation, Aksi Stop AIDS, dan IHPCP. 